\title{
Stable isotope dynamics of nitrogen recycled during interactions among marine bacteria and protists
}

\author{
Matthew P. Hoch ${ }^{1,3, *}$, Richard A. Snyder ${ }^{2}$, Luis A. Cifuentes ${ }^{1}$, Richard B. Coffin ${ }^{3}$ \\ ${ }^{1}$ Texas A\&M University, Department of Oceanography, College Station, Texas 77843, USA \\ ${ }^{2}$ University of West Florida, Center for Environmental Diagnostics and Bioremediation, Pensacola, Florida 32561, USA \\ ${ }^{3}$ U.S. Environmental Protection Agency, Gulf Ecology Division, Environmental, Gulf Breeze, Florida 32561, USA
}

\begin{abstract}
Variation in the distribution of stable nitrogen isotopes among different size classes of particulate organic nitrogen (PON) in aquatic environments may be partly explained by isotope effects associated with regeneration of $\mathrm{NH}_{4}{ }^{+}$by the microbial food web. Protists fed the marine bacterium Vibrio natriegens were grown in batch and continuous culture to define the isotope discrimination between $\mathrm{NH}_{4}{ }^{+}$, microbial biomass, and dissolved organic nitrogen (DON) for culture systems closed or open to exogenous nutrient inputs. In batch cultures of a flagellate Pseudobodosp. and a scuticociliate Uronema sp., the nitrogen isotope discrimination between biomass and $\mathrm{NH}_{4}{ }^{+}$was 3 to $5 \%$ during exponential growth of protists corresponding to the hughest rates of biomass-specific $\mathrm{NH}_{4}{ }^{*}$ release. The $\delta^{15} \mathrm{~N}$ of DON, calculated by mass balance, was very depleted ${ }^{15}{ }^{15} \mathrm{~N}$ relative to $\mathrm{NH}_{4}{ }^{+}$and biomass during exponential and early stationary growth when DON and dissolved free amino acid (DFAA) concentrations increased. In contrast to batch culture results, for continuous culture of the flagellate the isotope discrimination between biomass and $\mathrm{NH}_{4}{ }^{+}$and the change in the calculated $\delta^{15} \mathrm{~N}$ of DON were small: 1 to $2 \%$. Based on rates of thymidine incorporation and turnover of DFAA, protist excretion and bacterial uptake of DON were less coupled for exponentially growing protists fed starved bacteria in batch cultures than for the flagellate fed active bacteria growing in a 2 -stage continuous culture. Coupling between release and utilization of DON, as well as isotope effects associated with protist metabolism, are proposed to constrain the nitrogen isotope dynamics of $\mathrm{NH}_{4}{ }^{+}$, suspended PON, and DON within marine ecosystems, especially those environments dominated by regenerated primary production
\end{abstract}

KEY WORDS: Stable nitrogen isotopes - Protist grazing · Marine bacteria Ammonium regeneration Dissolved organic nitrogen

\section{INTRODUCTION}

Heterotrophic flagellates and ciliates are dominant consumers of bacteria and picophytoplankton in aquatic ecosystems (Andersen \& Fenchel 1985, Rassoulzadegan \& Sheldon 1986, Sherr et al. 1989, Caron et al. 1991) contributing to nitrogen recycling by excretion of $\mathrm{NH}_{4}^{+}$(Fenchel \& Finlay 1983, Goldman et al. 1985, Berman et al. 1987) and dissolved organic nitro-

\footnotetext{
- Present address: Malaspina University, Biology Department, Nanaimo, British Columbia, Canada V9R 5S5.

E-mail:hochm@mala.bc.ca
}

gen (DON) compounds (Andersson et al. 1985, Nagata \& Kirchman 1991, 1992). Ammonium excretion rates suggest that $>50 \%$ of regenerated nitrogen in the euphotic zone is supplied by protists (Ferrier-Pagès \& Rassoulzadegan 1994), especially in oligotrophic environments (Caron 1994). Protist release of dissolved amino acids can be $20 \%$ of ingested nitrogen and a mechanism for the feedback of substrates to bacteria (Nagata \& Kirchman 1991, 1992). Because protist grazing is an important control of nitrogen turnover in marine environments, protists may affect both the stable nitrogen isotope composition of $\mathrm{DON}$ and $\mathrm{NH}_{4}{ }^{+}$ used to support bacterial and phytoplankton produc- 
tion and the partitioning of ${ }^{15} \mathrm{~N}$ among size classes of particulate organic nitrogen (PON).

Variation in nitrogen isotope composition (reported as $\delta^{15} \mathrm{~N}$ ) of total PON, ranging from -3 to $11 \%$, has been extensively measured and discussed in terms of nitrogen sources and biogeochemical cycling (Saino \& Hattori 1980, Altabet \& McCarthy 1985, Cifuentes et al. 1988, Libes \& Deuser 1988). However, few investigations have measured or attempted to explain $\delta^{15} \mathrm{~N}$ variability among size classes of PON that are relevant to understanding sources of nitrogen for microbial biomass and microbial trophic dynamics $(<3 \mu \mathrm{m}$ PON). In the Sargasso Sea during winter, the $\delta^{15} \mathrm{~N}$ of $<1 \mu \mathrm{m}$ PON varied by $2.5 \%$ relative to $\mathrm{PON}>75 \mu \mathrm{m}$, and the discrimination between $\mathrm{PON}<3$ and $>3 \mu \mathrm{m}$ was about $2 \%$ in the euphotic zone (Altabet 1988). However, the variation in $\delta^{15} \mathrm{~N}$ with depth for these small size particles was $6 \%$, suggesting that either mineralization of suspended PON or disaggregation of sinking PON result in isotope fractionation (Altabet 1988). Rau et al. (1990) measured as much as $5 \%$ differences over a $<3$ to $>150 \mu \mathrm{m}$ size range of PON collected from surface waters of the northern Mediterranean coast, and annual variation in the $<8 \mu \mathrm{m}$ size fraction was $4 \%$. In both studies, about $50 \%$ of the PON was in the smaller size fraction $(<3 \mu \mathrm{m}$ PON) which contains most of the heterotrophic protist and bacterial biomass. These observations emphasize the importance of defining microbial processes contributing to $\delta^{15} \mathrm{~N}$ variation in small PON.

Differences in the $\delta^{15} \mathrm{~N}$ among small $(<3 \mu \mathrm{m})$ and larger PON may result partly from the sources of dissolved nitrogen assimilated by plankton components and isotope fractionation during uptake or release of nitrogen-containing compounds. Because $\mathrm{NH}_{4}{ }^{+}$is a preferred source of nitrogen for phytoplankton and can support most of the nitrogen demand of phytoplankton and bacteria, isotope effects associated with its uptake and regeneration within small PON versus larger $\mathrm{PON}$ may explain much of the $\delta^{15} \mathrm{~N}$ variability. Due to concentration-dependent partitioning of $\mathrm{NH}_{4}{ }^{+}$ uptake between plankton size classes (Suttle et al. 1990), larger phytoplankton will assimilate pulses of ${ }^{15} \mathrm{~N}$-depleted $\mathrm{NH}_{4}{ }^{+}$excreted by zooplankton (Checkley \& Miller 1989). Picophytoplankton and bacteria have a higher affinity for $\mathrm{NH}_{4}{ }^{+}$and will outcompete larger phytoplankton when $\mathrm{NH}_{4}{ }^{+}$concentrations are very low ( $<100 \mathrm{nM} \mathrm{NH}_{4}{ }^{+}$). Under these conditions, phytoplankton and bacteria will not fractionate $\mathrm{N}$ isotopes during $\mathrm{NH}_{4}{ }^{+}$uptake (Hoch et al. 1992, 1994, Fogel \& Cifuentes 1993). Therefore, in oligotrophic surface waters when $\mathrm{NH}_{4}{ }^{+}$regeneration is largely a result of protist metabolism, isotopic composition of picoplankton utilizing $\mathrm{NH}_{4}{ }^{+}$will be determined by the $\delta^{15} \mathrm{~N}$ of biomass grazed by protists and isotope fractionation associated with protist excretion of $\mathrm{NH}_{4}{ }^{+}$Thus, interactions of the microbial food web alone may account for variability within $<3 \mu \mathrm{m}$ PON and among larger PON.

Stable nitrogen isotope discrimination between $\mathrm{NH}_{4}{ }^{+}$and PON resulting from protist excretion of $\mathrm{NH}_{4}{ }^{+}$has not been measured. In the present study, the discrimination between $\delta^{15} \mathrm{~N}$ of excreted $\mathrm{NH}_{4}{ }^{+}$ and biomass was measured for 2 protist isolates, a flagellate, Pseudobodo sp., and a scuticociliate, Uronema sp. Both protists were fed the marine bacterium Vibrio natriegens. We hypothesized that $\mathrm{NH}_{4}{ }^{+}$ excreted by protists would be depleted in ${ }^{15} \mathrm{~N}$ by about $3 \%$ relative to the biomass, a result similar to that observed for zooplankton (Checkley \& Miller 1989) and to the $3 \%$ stepwise increase in $\delta^{15} \mathrm{~N}$ between trophic levels of higher organisms (e.g. Wada et al. 1987, Fry 1988). To compare nitrogen isotope discrimination for systems closed versus open to exogenous nutrient inputs, we used batch and continuous culture systems, respectively. Bacterial activity and dissolved free amino acid (DFAA) turnover and concentration were also measured to assess the dynamics of protist release and bacterial uptake of labile components of DON and to evaluate the potential contribution of bacteria to stable isotope dynamics in protist cultures.

\section{MATERIALS AND METHODS}

Two heterotrophic protists, a Pseudobodo sp. flagellate and a Uronema sp. scuticociliate, were isolated from Santa Rosa Sound, Florida, USA, by a nutrient enrichment technique. A $1 \mathrm{~cm}^{2}$ piece of agar from an LB media plate was added to $50 \mathrm{ml}$ volume of aseptically collected seawater, and after $3 \mathrm{~d}$, clones were established by micropipetting. Clonal cultures of protists were grown on the marine bacterium Vibrio natriegens. $V$. natriegens was grown on artificial seawater (Cavanaugh 1975) diluted to half strength ( $1 / 2 \mathrm{ASW} ; 16 \mathrm{ppt}$ salinity) and supplemented with $4 \mathrm{~g}$ Difco Nutrient Broth plus $2 \mathrm{~g}$ yeast extract. Bacterial cultures were harvested at stationary phase and then washed and resuspended in $1 / 2 \mathrm{ASW}$ to a final concentration of $5 \times 10^{7} \mathrm{ml}^{-1}$. Protist cultures were subsequently recloned to ensure culture purity prior to experiments. All protist incubations were performed at $18^{\circ} \mathrm{C}$.

For batch culture experiments, Vibrio natriegens cultures were harvested at stationary phase, washed twice in $1 / 2 \mathrm{ASW}$ without any nutrient supplement, and stored overnight. Prior to use in the experiment, the bacterial cell suspension was washed once again and then filtered through $3 \mu \mathrm{m}$ polycarbonate membrane (Poretics) to minimize clumped bacteria. Protist inocula were $1 \%$ of the experimental volume (11 l) and were 
taken from stationary phase cultures of protists to minimize carry-over of prey bacteria.

Two-stage continuous culture was used to grow the flagellate under relatively steady state conditions. In this experiment, the medium in a reservoir was fed to actively growing bacteria and effluent from the bacterial stage was used as an infeed for a flagellate growth stage. System dilution rate for a flagellate doubling time of about $20 \mathrm{~h}$ was about $0.0343 \mathrm{~h}^{-1}$. Medium was $60 \mathrm{mg} \mathrm{l}^{-1}$ Difco Nutrient Broth plus $30 \mathrm{mg} \mathrm{l}^{-1}$ yeast extract in $1 / 2 \mathrm{ASW}$. After Vibrio natriegens abundance in each stage had stabilized, the flagellate stage was inoculated. The experiment was sampled after $12 \mathrm{~d}$ (ca 10 turnovers).

Samples for particulate analysis were collected by filtration onto ashed glass fiber filters (Whatman GF/F type, combusted for 1 h at $500^{\circ} \mathrm{C}$ ), and filtrate was used for analysis of dissolved constituents. Concentrations of PON and particulate organic carbon (POC) were determined using a Carlo Erba NA1500 elemental analyzer. Concentrations of $\mathrm{NH}_{4}{ }^{+}$and nitrite plus nitrate were assayed according to Parsons et al. (1985). Total dissolved nitrogen (TDN) was measured by the method of Lòpez-Veneroni \& Cifuentes (1994). Dissolved free amino acid (DFAA) sample collection and analysis was according to Nagata \& Kirchman (1990) and used a reverse-phase HPLC technique modified from Mopper \& Lindroth (1982). Concentrations of unidentified amines were calculated assuming a fluorescence yield equal to that of glycine. Samples for bacterial and protist abundance were preserved with Lugol's iodine (Pomeroy 1984). Bacterial abundance was determined by epifluorescent direct counts of DAPI stained cells (Porter \& Feig 1980). Protist abundance was determined by phase-contrast microscopy using a hemocytometer for flagellates and by counting 10 to $100 \mu$ aliquots on a glass slide for ciliates.

Gross growth efficiencies were calculated for protist cultures as protist $\mathrm{C}$ or $\mathrm{N}$ yield divided by total organic $\mathrm{C}$ or $\mathrm{N}$ consumed. Protist $\mathrm{C}$ or $\mathrm{N}$ yield was calculated from total POC or PON in a culture minus the $\mathrm{POC}$ or PON contributed by bacteria. Bacterial organic $\mathrm{C}$ and $\mathrm{N}$ in protist cultures was estimated by multiplying bacterial cell abundance by the mean $\mathrm{C}$ or $\mathrm{N}$ content per Vibrio natriegens cell, which was determined from control incubations with only bacteria.

Rates of $\mathrm{NH}_{4}{ }^{+}$release were calculated as described by Nagata \& Kirchman (1991). Briefly, release rates were calculated as the change in $\mathrm{NH}_{4}{ }^{+}$concentration divided by the time interval between samples and then corrected for $\mathrm{NH}_{\mathrm{a}}{ }^{+}$produced in the bacterial control incubation. Biomass-specific rates were calculated by dividing release rates by average bacteria or protist $\mathrm{N}$ content for a sampling interval. Protist biomass nitro- gen was corrected for $\mathrm{N}$ content of residual prey bacteria

Incorporation rates of $\left[{ }^{3} \mathrm{H}\right.$-methyl]thymidine (TdR) and $\left[{ }^{14} \mathrm{C}\right.$ ]leucine (Leu) were determined in the batch culture experiment as an estimate of bacterial activity (Chin-Leo \& Kirchman 1988). Final concentrations of $\mathrm{TdR}$ and Leu were 40 and $80 \mathrm{nM}$, respectively. Incubations were for $10 \mathrm{~min}$ at $18^{\circ} \mathrm{C}$. Specific activity for Leu was corrected with the concentration of Leu measured by HPLC. In the continuous culture experiment, turnover rate $\left(\mathrm{h}^{-1}\right.$; incorporated radioactivity divided by total radioactivity) of DFAA was estimated with a $100 \mathrm{nM}$ final concentration of an $\left[{ }^{3} \mathrm{H}\right]$ amino acids mix (Amersham). Incubations were stopped at $2 \mathrm{~min}$ by rapid filtration, and filters were rinsed with $5 \mathrm{ml}$ of $1 / 2$ ASW. Mixed ester cellulose membranes with $0.45 \mu \mathrm{m}$ pore size (Millipore) were used for all radiolabel assays.

Nitrogen isotope analysis of $\mathrm{NH}_{4}{ }^{+}$and $\mathrm{PON}$ has been described (Hoch et al. 1992). Briefly, PON samples were collected onto glass fiber filters ( $47 \mathrm{~mm}$ Whatman $\mathrm{GF} / \mathrm{F}$ type, combusted for $1 \mathrm{~h}$ at $500^{\circ} \mathrm{C}$ ) and stored at $50^{\circ} \mathrm{C}$ under $\mathrm{N}_{2}$. Ammonium in the filtrate was recovered by alkaline distillation and adsorption of $\mathrm{NH}_{4}^{+}$ onto zeolite (Union Carbide molecular sieve W-85) (Velinsky et al. 1989). Both $\mathrm{NH}_{4}{ }^{+}$on zeolite and PON samples were converted to $\mathrm{N}_{2}$ by combustion with $\mathrm{CuO}$ and $\mathrm{Cu}$ in quartz tubes (Velinsky et al. 1989). Isotopic composition of $\mathrm{N}_{2}$ was measured on a Nuclide 360 mass spectrometer, and nitrogen isotope ratios were reported in the delta notation:

$$
\delta^{15} \mathrm{~N}=\left(X_{\text {sample }} / X_{\text {standard }}-1\right) \times 10^{3}
$$

where $X$ is ${ }^{15} \mathrm{~N}:{ }^{14} \mathrm{~N}$ and the standard, air, has a $\delta^{15} \mathrm{~N}=$ $0 \%$. Isotope discrimination for regeneration of $\mathrm{NH}_{4}{ }^{+}$ $\left(\Delta^{15} N_{R}\right)$ was calculated from the $\delta^{15} \mathrm{~N}$ of PON $(\delta \mathrm{PON})$ and $\mathrm{NH}_{4}{ }^{+}\left(\delta \mathrm{NH}_{4}{ }^{+}\right)$as follows:

$$
\Delta^{15} N_{R}=\delta_{\mathrm{PON}}-\delta_{\mathrm{NH}_{4}}{ }^{+}
$$

The $\delta$ N for DON in the cultures was calculated by isotopic mass balance:

$\delta_{\mathrm{DON}}=\left(\delta_{\mathrm{TN}} \times \mathrm{TN}-\delta_{\mathrm{PON}} \times \mathrm{PON}-\delta_{\mathrm{NH}_{4}}+\times \mathrm{NH}_{4}{ }^{+}\right) \times \mathrm{DON}^{-1}$

At the beginning of the experiment, DON $\delta^{15} \mathrm{~N}$ was assumed to equal PON $\delta^{15} \mathrm{~N}(3.5 \%)$ and this value was used to calculate the $\delta^{15} \mathrm{~N}$ of total nitrogen. Total nitrogen (TN) concentration was determined from the sum of PON and TDN. Total nitrogen concentration and $\delta^{15} \mathrm{~N}$ in the continuous culture system were measured directly from the nutrient broth/yeast extract media. The $\delta^{15} \mathrm{~N}$ of total organic nitrogen (TON) was calculated as:

$$
\delta_{\mathrm{TON}}=\left(\delta_{\mathrm{PON}} \times \mathrm{PON}+\delta_{\mathrm{DON}} \times \mathrm{DON}\right) \times \mathrm{TON}^{-1}
$$




\section{RESULTS}

\section{Closed system experiment}

Batch cultures of protists were designed to minimize the available substrates for bacterial growth in order to maximize the effects of protist metabolism on stable nitrogen isotope dynamics. Between 20 and $40 \mathrm{~h}$ in batch cultures the bacterial abundance decreased (Fig. 1A), flagellates and ciliates grew exponentially (Fig. 1B), and the $\mathrm{NH}_{4}{ }^{+}$concentration increased most rapidly (Fig. 1C). Bacterial abundance was relatively constant in the control incubation, i.e. the treatment without protists. Ammonium release rates were higher during exponential growth than during stationary phase for protists (Table 1), whereas this rate was constant throughout the experiment for the control $(0.08 \pm$ $0.002 \mu \mathrm{M} \mathrm{h}^{-1}$ ). Nitrate and nitrite were undetectable in all incubations. Loss of PON (Fig. 1D) and POC (not shown) was also greatest during exponential growth and they continued to decrease throughout stationary phase, but at a slower rate. A constant threshold density of bacteria $\left(5 \times 10^{6} \mathrm{ml}^{-1}\right)$ was maintained in the protist cultures after $35 \mathrm{~h}$. During exponential growth the $\mathrm{NH}_{4}{ }^{+}$release rate for the flagellate $\left(3.1 \mu \mathrm{M} \mathrm{h}^{-1}\right)$ was nearly twice that for the ciliate $\left(1.7 \mu \mathrm{M} \mathrm{h}^{-1}\right.$ ) (Table 1 ), although prey density decreased similarly. This difference is reflected in the lower $\mathrm{C}: \mathrm{N}$ ratio of 4 for the ciliate culture compared with the flagellate $\mathrm{C}: \mathrm{N}$ ratio of 5
Table 1. Ammonium production rates, specific growth rates, and growth efficiencies (GE) for batch cultures of heterotrophic protists. All values ( \pm SD) are for exponentual growth (25 to $45 \mathrm{~h} ; \mathrm{n}=5$ ), unless otherwise indicated

\begin{tabular}{|c|c|c|}
\hline Culture parameter & Flagellate & Ciliate \\
\hline $\begin{array}{l}\mathrm{NH}_{4} \text { production }\left(\mu \mathrm{Mh} \mathrm{h}^{-1} \text { ) }\right. \\
\text { (exponential growth) }\end{array}$ & $3.06( \pm 0.46)$ & $1.74( \pm 0.46)$ \\
\hline $\begin{array}{l}\mathrm{NH}_{4}^{+} \text {production }\left(\mu \mathrm{M} \mathrm{h}^{-1}\right) \\
\text { (stationary phase) }\end{array}$ & $0.46( \pm 0.07)$ & $0.52( \pm 0.08)$ \\
\hline Specific growth rate $\left(\mathrm{h}^{-1}\right)$ & $0.21( \pm 0.03)$ & $0.20( \pm 0.01)$ \\
\hline GE for carbon ${ }^{d}$ & $38( \pm 12)$ & $50( \pm 6.0)$ \\
\hline GE for nitrogen " & $28( \pm 10)$ & $54( \pm 5.1)$ \\
\hline \multicolumn{3}{|c|}{$\begin{array}{l}{ }^{\circ} \text { Growth efficiencies were corrected for bacterial biomass } \\
\text { using the sum of bacterial abundamce and mean } \mathrm{C} \text { or } \mathrm{N} \\
\text { content per cell }\left(5.9 \pm 0.45 \text { pmol } \mathrm{C} \mathrm{cell}^{-1} ; 1.4 \pm 0.08 \text { pmol. }\right. \\
\left.\mathrm{N} \text { cell }{ }^{-1}\right)\end{array}$} \\
\hline
\end{tabular}

(Fig. 1E) and a nitrogen-based growth efficiency for the ciliate $(54 \%)$ twice that for the flagellate $(28 \%)$ (Table 1).

The $\delta^{15} \mathrm{~N}$ of $\mathrm{NH}_{4}{ }^{+}$and PON in the bacterial control, flagellate, and ciliate batch cultures were determined during protist exponential growth and stationary phases (Fig. $2 \mathrm{~A}-\mathrm{C}$ ). Isotope discrimination for $\mathrm{NH}_{4}{ }^{+}$ regeneration $\left(\Delta^{15} \mathrm{~N}_{\mathrm{R}}=\delta_{\mathrm{PON}}-\delta_{\mathrm{NH}_{4}{ }^{+}}\right)$and the biomassspecific rate of $\mathrm{NH}_{4}{ }^{+}$release were calculated from the $\delta^{15} \mathrm{~N}$ and $\mathrm{NH}_{4}{ }^{+}$concentration data (Fig. 2D-F). In the
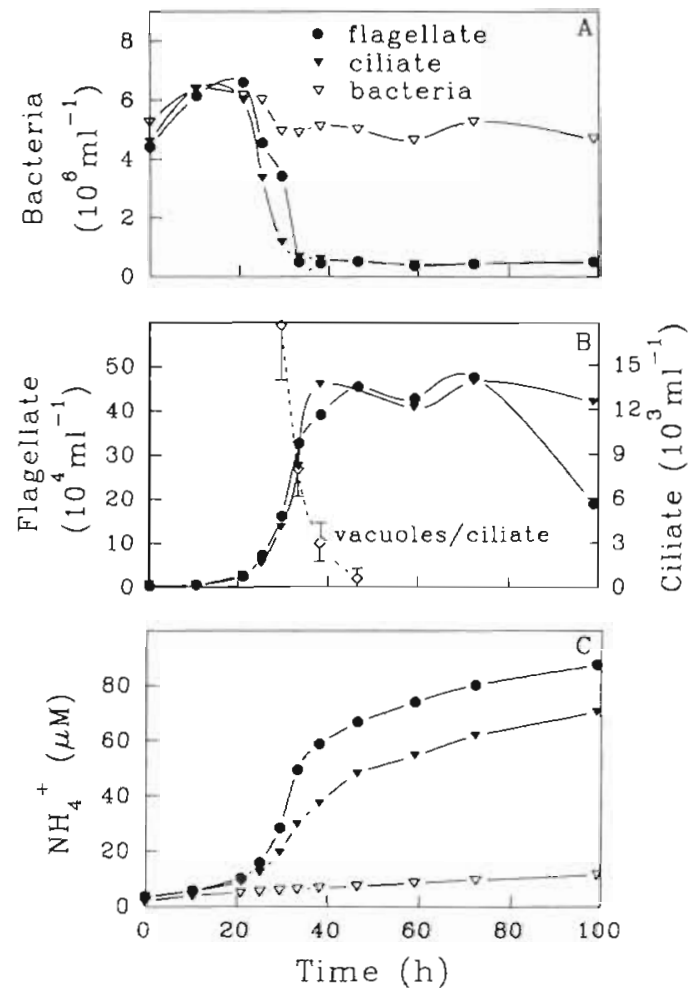
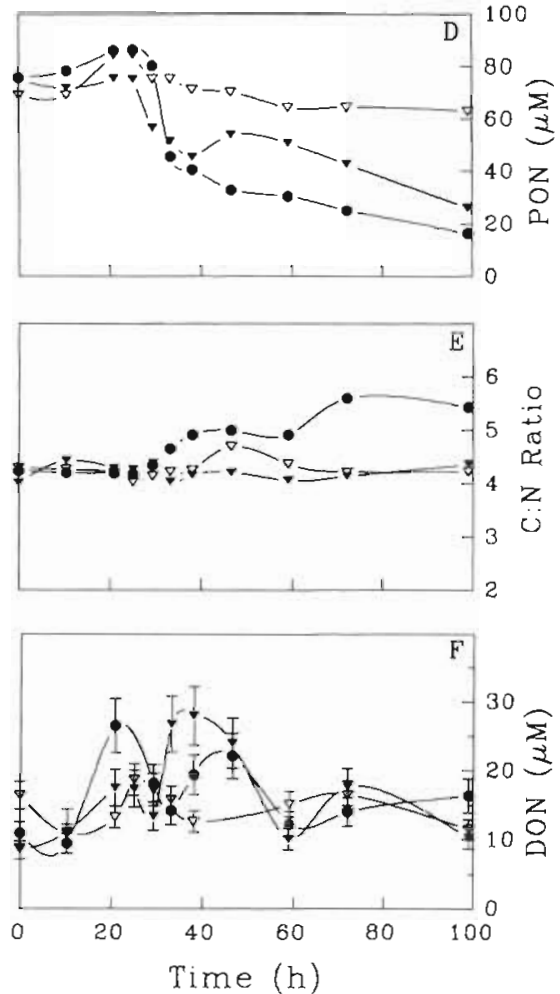

Fig. 1 (A) Bacterial abundance; (B) protist abundance and numbers of food vacuoles per ciliate (0); (C) $\mathrm{NH}_{4}{ }^{+} ;$(D) particulate organic nitrogen (PON); (E) C:N ratio of particulate organic matter; and (F) dissolved organic nitrogen (DON) for incubations of a flagellate Pseudoboda sp. (•) and a scuticociliate Uronema sp. ( $\mathbf{)}$, both fed washed cells of Vibrio natriegens, and only prey bacteria as a control $(\nabla)$. Error bars are for propagated SD 
Fig. 2. $\delta^{15} \mathrm{~N}$ for $\mathrm{NH}_{4}{ }^{4}(\nabla)$ and total particulate organic nitrogen (PON) (v) for incubations of (A) washed Vibrio natriegens alone, (B) the flagellate, or (C) the ciliate. $\delta^{15} \mathrm{~N}$ of $\mathrm{PON}$ was also corrected for the presence of bacterıal biomass in protist cultures ( $\pm \mathrm{SD} ; \mathbf{\square})$. Biomassspecific rates of $\mathrm{NH}_{4}{ }^{+}$ release were calculated as the average between sample intervals $(\theta)$ and compared to the nitrogen isotope discrimination between PON and $\mathrm{NH}_{4}{ }^{*}$
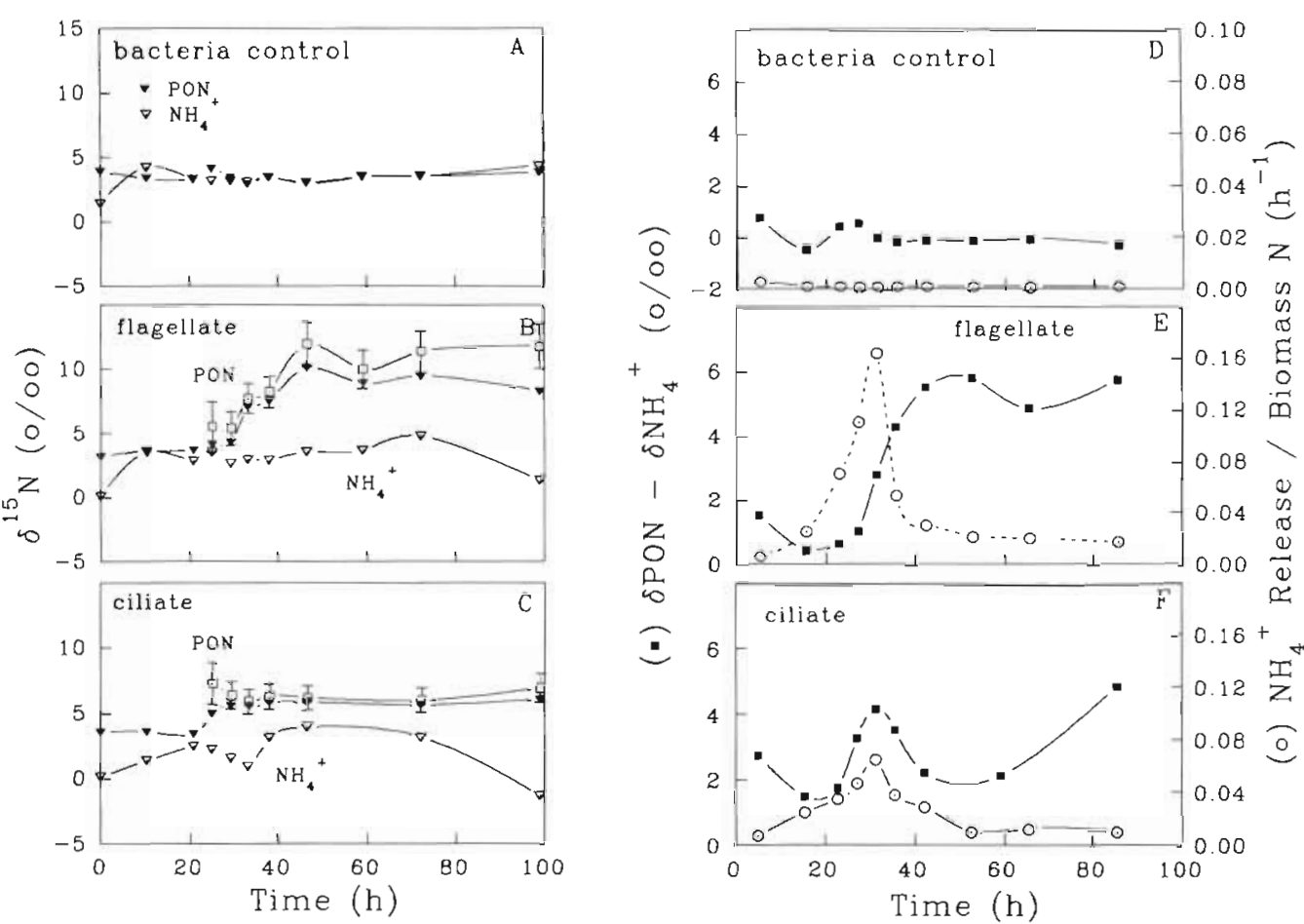

bacterial control, $\delta^{15} \mathrm{~N}$ of $\mathrm{NH}_{4}{ }^{+}$and PON were almost identical, averaging about $4 \%$ over the course of the experiment. This resulted in a $\Delta^{15} N_{R}$ of about $0 \%$. In contrast, the $\delta^{15} \mathrm{~N}$ of PON was more positive than that of $\mathrm{NH}_{4}{ }^{+}$in both protist cultures. The $\Delta^{15} \mathrm{~N}_{\mathrm{R}}$ varied from 3 to $5 \%$ during exponential growth (20 to $40 \mathrm{~h}$ ) of protists. For the flagellate, this was the result of $\mathrm{NH}_{4}{ }^{+} \delta^{15} \mathrm{~N}$ remaining constant and the PON $\delta^{15} \mathrm{~N}$ increasing. The maximum $\Delta^{15} N_{R}$ for the flagellate occurred after the maximum $\mathrm{NH}_{4}{ }^{+}$release rate and during the decrease in biomass-specific rates of $\mathrm{NH}_{4}{ }^{+}$release (Fig. $2 \mathrm{E}$ ). The discrimination in the ciliate culture was a net result of PON $\delta^{13} \mathrm{~N}$ increasing and $\mathrm{NH}_{4}{ }^{+} \delta^{15} \mathrm{~N}$ decreasing, and the maximum biomass-specific release of $\mathrm{NH}_{4}{ }^{+}$coincided with the maximum $\Delta^{15} \mathrm{~N}_{\mathrm{R}}$ at about $30 \mathrm{~h}$, during exponential growth (Fig. 2F). During stationary growth $(50$ to $70 \mathrm{~h})$, the discrimination for the flagellate was about $6 \%$, yet it was only $2.5 \%$ for ciliates. Discrimination increased to about $7 \%$ for both protists by $100 \mathrm{~h}$ (Fig. 2).

Estimates of $\Delta^{15} N_{R}$ reported above were based on the $\delta^{15} \mathrm{~N}$ of total PON rather than on the $\delta^{15} \mathrm{~N}$ of protist biomass alone. Although we could not separate protist and bacterial biomass for isotope analysis, we were able to calculate protist biomass $\delta^{15} \mathrm{~N}$ using a mass balance approach to subtract bacterial biomass from total PON. Calculation of bacterial biomass was based on bacterial abundance in the protist cultures and was assumed to have a $\delta^{15} \mathrm{~N}$ and nitrogen content per cell equal to bacteria in the control incubation (Fig. $2 \mathrm{~A}$ ). Correction for bacterial biomass in protist cultures resulted in only about a $1 \%$ increase in $\delta^{15} \mathrm{~N}$ PON (Fig. 2B, C).

Some other pool of $\mathrm{N}$ must have either changed in concentration, differed isotopically, or both, to have accounted for the constant $\delta^{15} \mathrm{~N}$ of $\mathrm{NH}_{4}{ }^{+}$and increasing $\delta^{15} \mathrm{~N}$ of PON in protist experiments. One explanation was that DON became depleted in ${ }^{15} \mathrm{~N}$ relative to $\mathrm{NH}_{4}{ }^{+}$ and PON. The $\delta^{15} \mathrm{~N}$ of DON was calculated for batch culture experiments based on mass balance of nitrogen isotopes (Eq. 3). When the protists were in mid-exponential growth $(30 \mathrm{~h}), \mathrm{DON} \delta^{15} \mathrm{~N}$ was lower than at $0 \mathrm{~h}$, particularly for the flagellate (Fig. 3). Concentration of DON varied by $20 \mu \mathrm{M}$ during exponential and early stationary growth of protists (Fig. 1F). At the end of the experiment, the calculated $\delta^{15} \mathrm{~N}$ increased to greater than $4 \%$ for both the flagellate and ciliate. In the con-

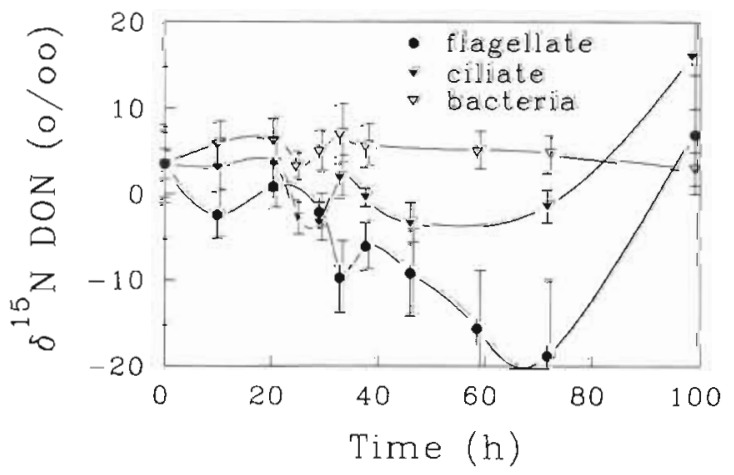

Fig. 3. $\delta^{15} \mathrm{~N}$ of DON calculated by isotope mass balance (Eq. 3). Error bars are for propagated SD 
trol., DON concentration and calculated $\delta^{15} \mathrm{~N}$ remained relatively constant.

Mechanisms that explain the variability in $\delta^{15} \mathrm{~N}$ values within batch cultures of protists and between the flagellate and ciliate may not be attributed solely to the protists. Interaction between protist release of DON and bacterial uptake and growth was apparent from the variation in DON concentration. Concentration of DFAA, a labile source of bacterial $C$ and $N$, varied similarly to concentration of DON, and DFAA in protist incubations were as much as 1 to $2 \mu \mathrm{M}$ greater than in the control (Fig. 4). Bacterial activity, measured as cell-specifi.c $T d R$ and Leu incorporation rates, decreased in the bacteria suspension and ciliate culture until about $40 \mathrm{~h}$ (Fig. 5). In contrast, bacterial activity increased while bacterial abundance decreased during flagellate exponential growth $(30 \mathrm{~h})$. Therefore, bacteria cell-specific rates of both $\mathrm{TdR}$ and Leu incorporation were enhanced (Fig. 5), and these results can be interpreted as an increase in bacterial growth rate during flagellate grazing. Although bacterial abundance did not change later in stationary phase, bacterial activity within both protist cultures increased concurrently with DFAA concentration and protist mortality, which was evident by decreased protist abundance and motility.

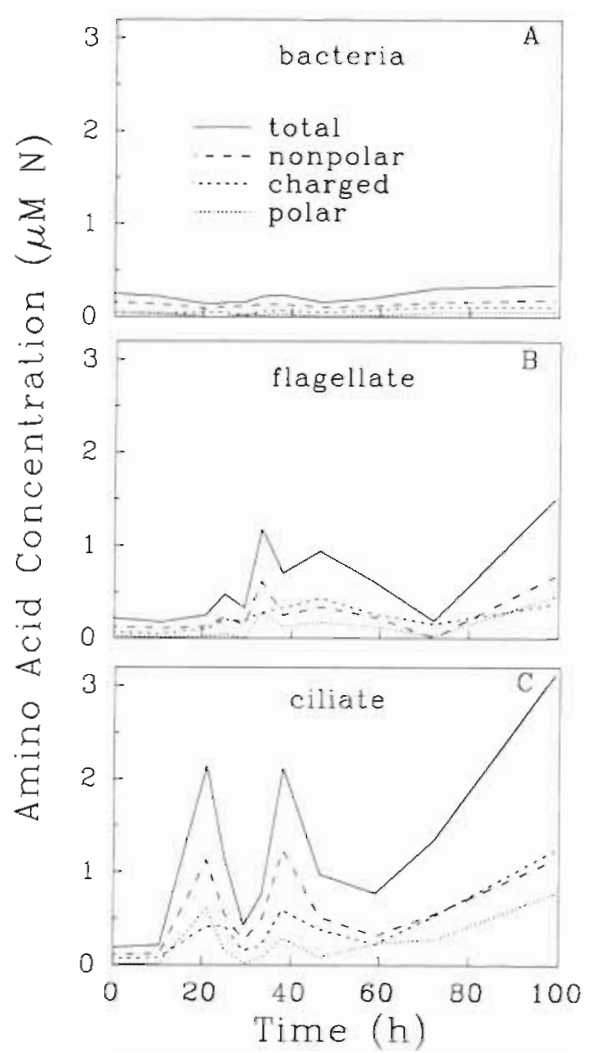

Fig. 4. Nitrogen concentrations of DFAA in batch incubations partitioned into groups of polar, nonpolar, and charged amino acids in addition to total DFAA
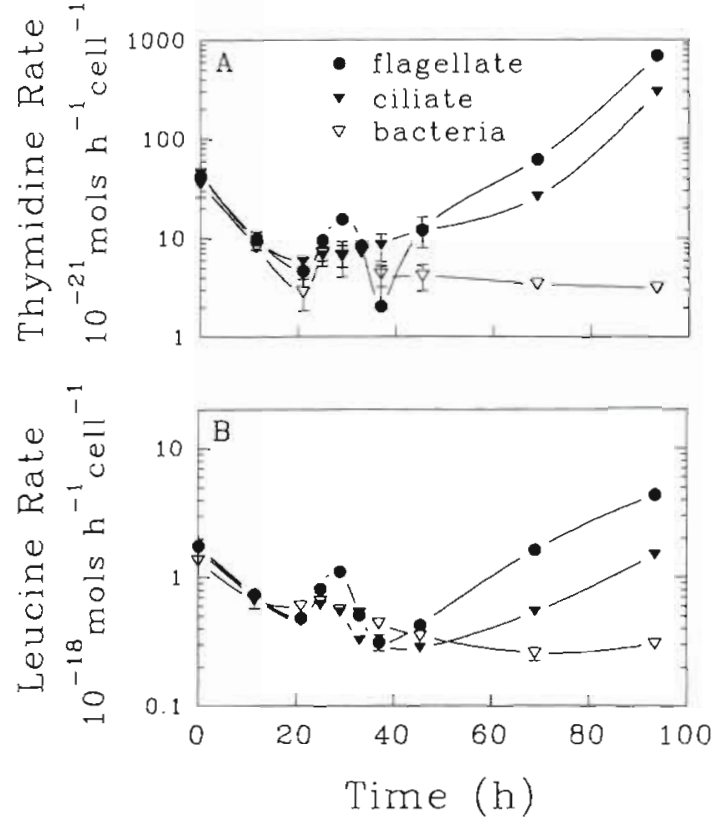

Fig. 5. Bacterial cell-specific rates of (A) thymidine and (B) leucine incorporation in batch incubations

In the closed system of batch cultures, bacteria in the washed cell suspensions used as protist prey were rapidly limited by substrate availability and no isotope discrimination was seen. However, in the presence of protist growth, there was release of substrates for bacteria, but release and uptake appeared uncoupled, i.e. release and uptake were not always at the same rate. As a result, concentrations of DFAA and total DON appeared as pulses and were greater than in the control. Exponential protist growth with minimal coupling of bacterial DON uptake to protist DON release appeared to result in significant changes in the isotope composition of nitrogen pools.

\section{Open system experiment}

Two-stage continuous culture provided a means to examine nitrogen isotope dynamics during growth of a phagotrophic flagellate and bacteria in an open system, i.e. with constant substrate input and biomass removal. The marine bacterium Vibrio natriegens grew in the first stage with the effluent feeding flagellates in the second stage. Bacterial abundance decreased from $9.4 \times 10^{7}$ to $2.2 \times 10^{7}$ cells $\mathrm{ml}^{-1}$ between the bacterial and flagellate stages. Flagellate density reached $2.3 \times$ $10^{5}$ cells $\mathrm{ml}^{-1}$. Concentrations of PON were similar for both stages, but $\mathrm{NH}_{4}{ }^{+}$increased by about $260 \mu \mathrm{M}$ in the flagellate stage (Table 2 ). The biomass-specific rate of $\mathrm{NH}_{4}{ }^{+}$release in the bacterial stage was $0.043 \mathrm{~mol}$. $\mathrm{NH}_{4}^{+}$released (mol bacterial $\mathrm{N}^{-1} \mathrm{~h}^{-1}$, which was about 
Table 2. Nitrogen concentration and $\delta^{15} \mathrm{~N}$ for $\mathrm{NH}_{\alpha}{ }^{+}$, particulate organic nitrogen ( $\mathrm{PON}$ ), and dissolved organic nitrogen (DON) for a 2-stage continuous culture where medium was fed to the bacterium Vibrio natriegens in the first stage which then fed the flagellate protist in the second stage. System dilution rate was $0.0343 \mathrm{~h}^{-1}$

\begin{tabular}{|c|c|c|c|c|c|c|}
\hline \multirow{2}{*}{$\begin{array}{l}\text { Culture } \\
\text { system } \\
\text { stage }\end{array}$} & \multicolumn{3}{|c|}{$[N](\mu \mathrm{M})$} & \multicolumn{3}{|c|}{$\delta^{15} \mathbb{N}(\%)$} \\
\hline & $\mathrm{NH}_{4}^{+}$ & $\mathrm{DON}^{\mathrm{i}}$ & PON & $\mathrm{NH}_{4}{ }^{+}$ & PON & DON \\
\hline Medium & 11 & 890 & - & - & - & 5.3 \\
\hline Bacteria & 229 & 499 & 173 & 1.2 & 5.3 & 7.3 \\
\hline Protist & 486 & 243 & 172 & $3.4^{c}$ & $7.9^{d}$ & 6.7 \\
\hline \multicolumn{7}{|c|}{$\begin{array}{l}{ }^{a} \text { DON was calculated from TDN }-\left(\mathrm{NH}_{4}{ }^{+}+\text {PON }\right) \text {, where } \\
\text { TDN was } 900 \mu \mathrm{MN}\end{array}$} \\
\hline \multicolumn{7}{|c|}{$\begin{array}{l}{ }^{b} \text { The } \delta^{15} \mathrm{~N} \text { for DON in each culture stage was estimated by } \\
\text { isotopic mass balance using the } \delta^{15} \mathrm{~N} \text { and concentration of } \\
\text { PON, } \mathrm{NH}_{4}^{+} \text {, and } \mathrm{N} \text { in the medium }\end{array}$} \\
\hline \multicolumn{7}{|c|}{$\begin{array}{l}{ }^{c} \text { The } \delta^{15} \mathrm{~N} \text { for } \mathrm{NH}_{4}{ }^{+} \text {produced in the flagellate stage was } \\
5.4 \% \text { based on an isotope mass balance correction for the } \\
\mathrm{NH}_{4}{ }^{+} \text {produced in the bacterial stage }\end{array}$} \\
\hline \multicolumn{7}{|c|}{$\begin{array}{l}\text { The } \delta^{15} \mathrm{~N} \text { for flagellate biomass was calculated to be } 8.4 \% \\
\text { by subtracting bacterial biomass from the protist stage } \\
\text { and assuming that bacteria in the protist stage have the } \\
\text { same } \delta^{15} \mathrm{~N} \text { as DON in the bacterial stage }\end{array}$} \\
\hline
\end{tabular}

20 times greater than the rates calculated for the 'starved' bacteria in the control incubation of the batch culture experiment (Fig. 2D). The flagellate biomassspecific rate was $0.053 \mathrm{~mol} \mathrm{NH}_{4}{ }^{+}$(mol flagellate $\left.\mathrm{N}\right)^{-1}$ $\mathrm{h}^{-1}$ after correcting for the bacterial contribution to $\mathrm{NH}_{4}^{+}$release in the flagellate stage. The biomassspecific rate of $\mathrm{NH}_{4}{ }^{+}$release by the flagellate in continuous culture was within the range of values calculated for flagellate exponential growth in batch culture (Fig. 2E). Nitrogen-based gross growth efficiency for the flagellate was $27 \%$, which was also similar to the value for exponential growth of the flagellate in batch culture (Table 1). The similarity in N physiology for the flagellate grown in batch and continuous culture suggests that bacterial metabolism may largely be responsible for differences in nitrogen isotope dynamics between the closed and open culture systems.

Bacteria were important in mineralizing amino acids in the continuous culture experiment. About $80 \%$ of $N$ in the medium was in the form of DFAA. However, much of the DFAA consumption within the bacterial stage of the continuous culture did not convert to biomass or $\mathrm{NH}_{4}{ }^{+}$. Only $400 \mu \mathrm{M}$ of the $680 \mu \mathrm{M}$ decrease in DFAA in the bacterial stage (Fig. 6) was accounted for as $\mathrm{NH}_{4}^{+}$and PON (Table 2), which suggested that $280 \mu \mathrm{M}$ of DFAA nitrogen was converted to other DON, such as extracellular enzymes. The concentrations of total DON (Table 2) and specific DFAAs (Fig. 6) remaining in the bacterial stage decreased in the flagellate stage, whereas Leu and 1 unidentified amine

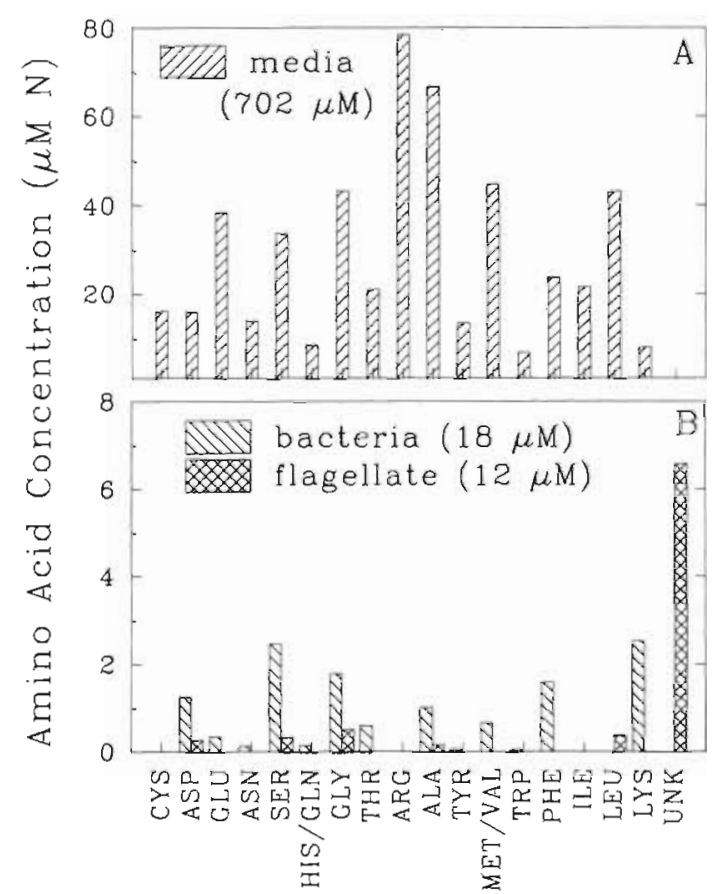

Fig. 6. Concentrations of DFAA nitrogen in the medium (A) and bacterial and flagellate stages (B) of the continuous culture experiment. Total concentration of DFAA nitrogen is given in parentheses

increased between stages. The turnover rate for DFAA in the flagellate stage culture was $4.3 \pm 0.7 \mathrm{~h}^{-1}$. The system dilution rate was about 2 orders of magnitude lower $\left(0.0343 \mathrm{~h}^{-1}\right)$ (Table 3$)$, suggesting a rapid recy-

Table 3. Comparison of protist growth parameters and isotope discrimination between nitrogen pools for protists in batch and continuous culture

\begin{tabular}{|c|c|c|}
\hline & $\begin{array}{l}\text { Closed } \\
\text { (batch) }\end{array}$ & $\begin{array}{c}\text { Open } \\
\text { (continuous) }\end{array}$ \\
\hline Protist growth rate & $0.21 \mathrm{~h}^{-1}$ & $0.034 \mathrm{~h}^{1}$ \\
\hline Amino acid turnover & 0.05 to $0.5 \mathrm{~h}^{-1}$ & $4.3 \mathrm{~h}^{-1}$ \\
\hline Bacterial $\mathrm{NH}_{4}$ release & $0.002 \mathrm{~h}^{-1}$ & $0.043 \mathrm{~h}^{-1}$ \\
\hline Macroblal interactions & Uncoupled & Coupled \\
\hline$\Delta^{15} \mathrm{~N}\left(\mathrm{TON}-\mathrm{NH}_{4}{ }^{+}\right)$ & 0 to $1 \%$ & 1 to $2 \%$ \\
\hline$\Delta^{15} N\left(\mathrm{PON}-\mathrm{NH}_{4}\right)^{\mathrm{C}}$ & 4 to $7 \%$ & 0 to $3 \%$ \\
\hline$\Delta^{15} \mathrm{~N}(\mathrm{PON}-\mathrm{DON})^{\mathrm{C}}$ & 10 to $15 \%$ & $1 \%$ \\
\hline$\Delta^{15} \mathrm{~N}\left(\mathrm{NH}_{4}{ }^{+}-\mathrm{DON}\right)^{d}$ & 5 to $8 \%$ & $-1 \%$ \\
\hline \multicolumn{3}{|c|}{$\begin{array}{l}\text { 'Leucine turnover was given for the batch culture experi- } \\
\text { ment }\end{array}$} \\
\hline \multicolumn{3}{|c|}{$\begin{array}{l}\text { 'Biomass-specific release of } \mathrm{NH}_{4}{ }^{+} \text {was reported in units of } \\
\text { mols } \mathrm{NH}_{4}^{+} \text {(mol biomass } \mathrm{N}^{-1} \mathrm{~h}^{-1}\end{array}$} \\
\hline \multicolumn{3}{|c|}{$\begin{array}{l}\text { "High values were calculated using the } \delta P O N \text { for flagel- } \\
\text { late biomass, which was derived by subtracting bacterial } \\
\text { biomass from total PON in the protist culture (see Table } 2 \text { ) }\end{array}$} \\
\hline \multicolumn{3}{|c|}{$\begin{array}{l}\text { "Values for } \delta D O N \text { were calculated from isotope mass bal- } \\
\text { ance (Eq. 3) }\end{array}$} \\
\hline
\end{tabular}


cling of organic matter between bacteria and flagellates and that bacteria grew in the protist stage and contributed to $\mathrm{NH}_{4}{ }^{+}$release.

Isotope discrimination between pools of $\mathrm{N}$ during continuous culture of the flagellate was lower than in protist batch cultures, but higher than in the bacterial control for the batch culture experiment. There was no isotope discrimination between the medium DON $\left(\delta^{15} \mathrm{~N}=5.3 \%\right)$ and the bacterial biomass in the first stage $(5.3 \%)$ (Table 2$)$, but discrimination between $\mathrm{NH}_{4}{ }^{+} \delta^{15} \mathrm{~N}$ and PON $\delta^{15} \mathrm{~N}$ in bacteria was $-4 \%$ (Table 2). In contrast, there was no difference in $\delta^{15} \mathrm{~N}$ for $\mathrm{NH}_{4}{ }^{+}$and PON in the washed cell suspension used for batch cultures (Fig. 2A). In the flagellate stage the $\delta^{15} \mathrm{~N}$ PON increased to $7.9 \%$ and $\mathrm{NH}_{4}{ }^{+} \delta^{15} \mathrm{~N}$ increased to $3.4 \%$ relative to the bacterial stage. Correcting the $\mathrm{NH}_{4}{ }^{+} \delta^{15} \mathrm{~N}$ for the flagellate stage by subtracting the bacterial stage $\mathrm{NH}_{4}{ }^{+}\left(243 \mu \mathrm{M}\right.$ of $\left.1.2 \% \mathrm{NH}_{4}{ }^{+}\right)$gives an $\mathrm{NH}_{4}{ }^{+} \delta^{15} \mathrm{~N}$ of $5.4 \%$. Therefore, the $\Delta^{15} \mathrm{~N}_{\mathrm{R}}$ would be $2.5 \%$ when calculated from PON $\delta^{15} N$ for the flagellate stage, but $\Delta^{15} \mathrm{~N}_{R}$ equaled $0 \%$ when the PON $\delta^{15} \mathrm{~N}$ from the bacterial stage was used in the calculation.

\section{DISCUSSION}

Batch culture of protists fed Vibrio natriegens starved of any supply of organic nutrients results in greater isotope discrimination between $N$ pools than for protists fed bacteria growing on exogenously supplied organic medium in the 2-stage continuous culture (Table 3). The isotope discrimination for $\mathrm{NH}_{4}{ }^{+}$ regeneration $\left(\Delta^{15} N_{R}\right)$ is about 3 to $5 \%$ during midexponential growth in both flagellate and ciliate batch cultures and coincides with maximum rates of protist biomass-specific release of $\mathrm{NH}_{4}^{+}$. These values are consistent with 3 to $3.5 \%$ increases between trophic levels of macroorganisms (Wada et al. 1987, Fry 1988) and the $3 \%$ discrimination between zooplankton biomass and excreted $\mathrm{NH}_{4}{ }^{+}$(Checkley \& Miller 1989). In contrast to zooplankton (Checkley \& Miller 1989), the discriminations in our batch cultures are largely due to a increasing $\delta^{15} \mathrm{~N}$ of PON rather than a constant $3 \%$ depletion of ${ }^{15} \mathrm{~N}$ in excreted $\mathrm{NH}_{4}{ }^{+}$, which suggests that another form of $\mathrm{N}$ is important for maintaining isotopic mass balance. There are transient accumulations of DFAA and total DON pools in batch cultures, and DON may be an isotopically dynamic pool of nitrogen in these experiments.

Grazer ingestion rate, which decreases from exponential to stationary growth, can affect the relative proportion of $\mathrm{NH}_{4}{ }^{+}$and $\mathrm{DON}$ egested by grazers (Jumars et al. 1989) The bacterivorous marine flagellate Paraphysomonas imperforata releases nearly equal proportions of egested $\mathrm{NH}_{4}^{+}$and DFAA when ingestion rate is high during exponential growth, whereas 80 to $90 \%$ of the egested $\mathrm{N}$ is $\mathrm{NH}_{4}{ }^{+}$during stationary phase (Nagata \& Kirchman 1991). A portion of the $\mathrm{NH}_{4}{ }^{*}$ released during stationary phase may result from catabolism of internal reserves accumulated during high prey abundance. Catabolism of internal reserves is apparent during early stationary phase of our ciliate culture as food vacuole number decreased to zero (Fig. 1B). Catabolism of a ${ }^{15} \mathrm{~N}$ enriched reserve may account for the shift to a smaller $\Delta^{15} N_{R}$ during ciliate stationary phase. An alternative explanation for a higher fraction of egested $\mathrm{N}$ as $\mathrm{NH}_{4}{ }^{+}$ in batch cultures of protists is bacterial utilization of released DON compounds and subsequent bacterial regeneration of $\mathrm{NH}_{4}{ }^{+}$

The release and accumulation of labile DON, such as DFAA, and the subsequent stimulation of bacterial growth and excretion of $\mathrm{NH}_{4}^{+}$are factors to consider when interpreting the nitrogen isotope results. Transient accumulations in DFAA and total DON and stimulation of bacterial growth are apparent during exponential growth and late stationary phase of protists in batch cultures. Assuming a 50\% growth efficiency, bacteria grown on low $C: N$ substrates $(C: N<10)$, such as amino acids, will regenerate $\mathrm{NH}_{4}^{+}$(Goldman et al. 1987). Because the total organic matter had a $C: N$ ratio of about 4 in both our batch and continuous culture systems, bacteria were probably active agents of $\mathrm{NH}_{4}{ }^{+}$ production once they responded to DON release. The high rate of $\mathrm{NH}_{4}{ }^{+}$release by bacteria growing on DFAA and rapid turnover of DFAA in continuous culture emphasize the potential for a bacterial contribution to $\mathrm{NH}_{4}{ }^{+}$regeneration during protist grazing. Because our results suggest protist release and bacterial uptake of DON, any isotope discrimination between $\mathrm{N}$ pools is the net result of several processes, only one of them being excretion of $\mathrm{NH}_{4}{ }^{+}$by protists.

The isotope fractionation for bacterial regeneration of $\mathrm{NH}_{4}{ }^{+}$would have largely influenced the $\Delta^{15} \mathrm{~N}_{\mathrm{R}}$ observed in protist cultures when bacterial activity was enhanced by a supply of substrate. The degree of isotope discrimination between PON and $\mathrm{NH}_{4}{ }^{+}$in bacterial controls for continuous and batch cultures apparently relates to a difference in the supply of exogenous organic nutrients for bacterial growth. There is no isotope discrimination when there is relatively little substrate for growth, such as in the bacterial control for the batch cultures. In contrast, bacterial growth on a continuous supply of DFAA-rich medium $180 \%$ of medium DON) results in $\mathrm{NH}_{4}{ }^{+} 4 \%$ depleted in ${ }^{15} \mathrm{~N}$ relative to PON. The discrimination for Vibrio natriegens growth on a complex medium is the net result of isotope effects associated with assimilation, deamination, and transamination for many different compounds (Macko et al. 1986, 1987). This discrimination value will change 
depending on the composition of the DON supply; for example, $V$. natriegens grown on glutamate alone has a $\Delta^{15} N_{R}$ of $-7 \%$ (M. P. Hoch unpubl.).

What is difficult to explain is the calculated depletion of ${ }^{15} \mathrm{~N}$ in the DON relative to $\mathrm{NH}_{4}{ }^{*}$ and PON in protist batch cultures. The DON pool must decrease in ${ }^{15} \mathrm{~N}$ content to account for the increase in PON $\delta^{15} \mathrm{~N}$ without a balanced decrease in $\mathrm{NH}_{4}{ }^{+} \delta^{15} \mathrm{~N}$. Certainly, the magnitudes of DON $\delta^{15} \mathrm{~N}$ estimates generated by Eq. (3) are sensitive to the assumption that the initial DON is isotopically similar to the PON $(3.5 \%)$. As an extreme example, had the DON pool been much more enriched in ${ }^{15} \mathrm{~N}$ than $3.5 \%$, the bacterial uptake of the DON would have caused an increase in PON $\delta^{15} \mathrm{~N}$ during protist growth and little change in DON $\delta^{15} \mathrm{~N}$. However, this example does not seem to be the case, because the PON $\delta^{15} \mathrm{~N}$ for bacteria in the control would have also increased rather than remain constant. In protist batch cultures, the calculated changes in DON $\delta^{15} \mathrm{~N}$ occur after bacteria are grazed down to a threshold abundance at about $30 \mathrm{~h}$, implying that DON release by protists or DON recycling by bacteria partitions ${ }^{14} \mathrm{~N}$ into the DON pool. Accumulation of dissolved compounds depleted in ${ }^{15} \mathrm{~N}$ relative to other pools or the isotope fractionation of compounds released by passive diffusion may both explain the ${ }^{15} \mathrm{~N}$-depleted DON pool. Some amino acids accumulate while others are utilized in protist cultures (Fig. 4; Fig. 6), but it is doubtful that accumulation of any one compound is responsible for the calculated depletion of ${ }^{15} \mathrm{~N}$ in DON over time.

Dramatic changes in the $\delta^{15} \mathrm{~N}$ of nitrogen pools at the end of batch culture experiments $(>70 \mathrm{~h})$ can be explained by a complexity of events. During this time, bacterial activity increased 10 -fold and there was evidence of protist mortality. Calculated values of DON $\delta^{15} \mathrm{~N}$ increased by about $+15 \%$ for both cultures between 73 to $98 \mathrm{~h}$, whereas $\mathrm{NH}_{4}{ }^{+} \delta^{15} \mathrm{~N}$ decreased by $4 \%$ during this time. This decrease in $\mathrm{NH}_{4}{ }^{+} \delta^{15} \mathrm{~N}$ is the result of a $10 \mu \mathrm{M}$ increase in $\mathrm{NH}_{4}{ }^{+}$concentration over $15 \mathrm{~h}$, which suggests that average $\mathrm{NH}_{4}{ }^{+} \delta^{15} \mathrm{~N}$ during this time had to be $-15 \%$ in the flagellate culture and $-28 \%$ for the ciliate. A possible mechanism for such a large depletion of ${ }^{15} \mathrm{~N}$ in $\mathrm{NH}_{4}{ }^{+}$could be bacterial $\mathrm{NH}_{4}{ }^{+}$ excretion and the isotope effects associated with the reactions involved, i.e. uptake of DON compounds, deamination reactions (-14\%; Macko et al. 1987), and excretion via passive membrane diffusion of $\mathrm{NH}_{3}$ $\left(-39 \%\right.$; O Leary 1978). Increase in DON $\delta^{15} \mathrm{~N}$ at the end of the experiment could result from a ${ }^{15} \mathrm{~N}$-enriched source of DON, such as the protist biomass $(10$ to $12 \%$ ). If protist-derived DON is highly proteinaceous, then DON could be as much as $3 \%$ enriched relative to total biomass (Macko et al. 1987). Isotope fractionation during protein hydrolysis (S. Macko pers. comm. reported in Altabet et al. 1991) and uptake of DON compounds by bacteria would contribute to ${ }^{15} \mathrm{~N}$ enrichment of DON. Therefore, it seems that some increase in DON $\delta^{15} \mathrm{~N}$ is reasonable.

Overall, the levels of discrimination among nitrogen pools during flagellate growth are lower in magnitude for continuous culture (open system), where the bacterial prey are supplied substrates for growth, than during exponential growth in batch cultures (closed system), where bacteria are starved of substrates until after protist release of DON (Table 3). The difference in magnitude of isotope discrimination between open and closed culture systems appears to be related to the degree of coupling between protist release and bacterial uptake of DON (Fig. 7). Turnover rates of DON components are one way of assessing the degree of coupling. Turnover rates of DFAA for the continuous culture exceeded the culture system dilution rate by 2 orders of magnitude and are similarly greater than leucine turnover during exponential growth of the flagellate (Table 3 ). The bacteria in the continuous culture system are much more important to $\mathrm{NH}_{4}{ }^{+}$regeneration than the bacteria in batch cultures, and their biomass-specific rate of $\mathrm{NH}_{4}{ }^{+}$release is comparable to that of the flagellate. Bacteria in the 2-stage continuous

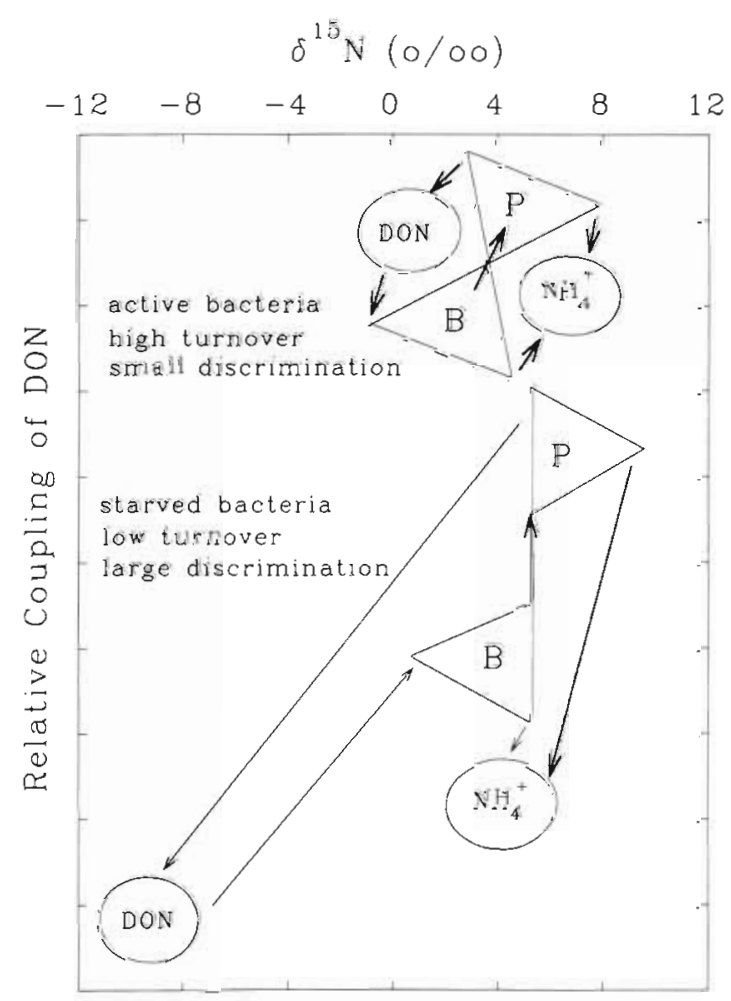

Fig. 7. Schematic representation of how the relative coupling between protist grazing, DON release, and bacteria uptake of DON relates to the magnitude of nitrogen isotope discriminations between particulate and dissolved $\mathrm{N}$ forms 
culture are able to sustain a higher metabolic rate than bacteria in batch cultures due to constant release of labile DON by the protist. Therefore, continuous culture provides a means to maintain a steady state, or tight coupling, between protist release and bacterial uptake of labile DON. When the coupling between flagellates and bacteria is not in steady state, as in the batch culture, grazing has a large effect on the isotope composition of biomass and DON (Table 3, Fig 7). Rapid recycling of organic nitrogen and regeneration of ammonium by both the flagellate and bacteria in continuous culture appears to homogenize the distribution of stable nitrogen isotopes among $\mathrm{PON}, \mathrm{NH}_{4}{ }^{+}$, and DON (Table 3). Protist-bacteria interactions between our closed (batch) and open (continuous) culture systems represent extremes of what may happen in the environment.

The impact of isotope effects associated with regeneration of $\mathrm{NH}_{4}{ }^{4}$ by bacteria or protists on the PON $\delta^{15} \mathrm{~N}$ in systems dominated by new production is predicted to be small (Nakatsuka et al. 1992). Of course, this result is due to a high fraction of the PON standing stock being supported by sources of new production and does not suggest that isotope effects during regeneration are insignificant. Variability in $\delta^{15} \mathrm{~N}$ within the size class of PON relevant to protist-bacteria interactions has been observed over seasonal scales in coastal waters (Rau et al. 1990), where sources for new production would be higher than in oligotrophic oceanic environments. It is uncertain to what extent such varjability is a result of changing the $\delta^{15} \mathrm{~N}$ of nitrogen sources to the microbial community, the variation in the dominant form of nitrogen taken up (e.g. $\mathrm{NH}_{4}{ }^{+}$and DON), or the degree of coupling between predator and prey production and turnover of labile DON components.

In oligotrophic ecosystems where regenerated production predominates and microbial biomass is the majority of total suspended PON, we speculate that coupled microbial processes may vary the nitrogen isotope composition of PON and DON over temporal and spatial scales by about $2 \%$. Because protists have been implicated in the degradation and disaggregation of detritus (Sherr et al. 1982), changes in PON $\delta^{15} \mathrm{~N}$ for decomposing phytoplankton (Wada 1980) and sinking particles relative to suspended PON (Altabet 1988, 1989, Altabet et al. 1991) may partially be the result of bacterivorous protist activity. Our results suggest that ${ }^{15} \mathrm{~N}$ enrichment of degrading PON and production of ${ }^{15} \mathrm{~N}$ depleted $\mathrm{NH}_{4}{ }^{+}$or DON will depend on the degree of coupling between release and uptake of DON by protists and bacteria, which may differ for suspended and sinking PON. Transformations of nitrogen within the microbial food web, such as those reported here, may be an important mechanism for the redistribution of ${ }^{15} \mathrm{~N}$ within the euphotic zone of the oceans, and could account for discrepancies observed in ${ }^{15} \mathrm{~N}$ budgets based solely on PON stocks, PON flux, and nitrate flux by generating DON of 'intermediate' $\delta^{15} \mathrm{~N}$ values (Altabet 1989).

Acknowledgements. We thank Jim Dugger and Lynn Roelke for technical assistance. This work was supported by NSF grant OCE 91-16756 to L.A.C. and R.B.C. and EPA cooperative agreement CR818676-01-0 to R.A.S.

\section{LITERATURE CITED}

Altabet MA (1988) Variation in nitrogen isotope composition between sinking and suspended particles: implications for nitrogen cycling and particle transformation in the open ocean. Deep Sea Res 35:535-554

Altabet MA (1989) A time-series study of the vertical structure of nitrogen and particle dynamics in the Sargasso Sca. Limnol Oceanogr 34:1185-2101

Altabet MA, Deuser WG, Honjo S, Stienen C (1991) Seasonal and depth-related changes in the source of sinking particles in the North Atlantic. Nature 354:136-139

Altabet MA, McCarthy JJ (1985) Temporal and spatial variations in the natural abundance of ${ }^{15} \mathrm{~N}$ in $\mathrm{PON}$ from a warm-core ring. Deep Sea Res 32:755-772

Andersen P, Fenchel T (1985) Bacterivory by microheterotrophic flagellates in seawater samples. Limnol Oceanogr 30:198-202

Andersson A, Lee C, Azam F, Hagström ^ (1985) Release of amino acids and inorganic nutrients by heterotrophic marine microflagellates. Mar Ecol Prog Ser 23:99-106

Berman T, Nawrocki M. Taylor GT, Karl DM (1987) Nutrient flux between bacteria, bacterivorous nanoplanktic protists, and algae. Mar microb Food Webs 2:69-82

Caron DA (1994) Grazer control of nutrient remineralization: the role of protozoa. EOS 75:231

Caron DA, Lim EL, Miceli GM, Waterbury JB, Valois FW (1991) Grazing and utilization of chroococcoid cyanobacteria and heterotrophic bacteria by protozoa in laboratory cultures and a coastal plankton community. Mar Ecol Prog Ser 76:205-217

Cavanaugh GM (1975) Formulae and methods of the Marine Biological Laboratory chemical room. Marine Biological Laboratory, Woods Hole

Checkley DM, Miller CA (1989) Nitrogen isotope fractionation by oceanic zooplankton. Deep Sea Res 36:1449-1456

Chın-Leo G, Kirchman DL (1988) Estimating bacterial production in marine waters from the simultaneous incorporation of thymidine and leucine. Appl environ Microbiol 54:1934-1939

Cifuentes LA, Sharp JH, Fogel ML (1988) Stable carbon and nitrogen isotope biogeochemistry in the Delaware estuary. Limnol Oceanogr 33:1102-1115

Fenchel T, Finlay BJ (1983) Respiration rates in heterotrophic, free living protozoa. Microb Ecol 9:99-1.22

Ferrier-Pagès C. Rassoulzadegan F (1994) N remineralization in planktonic protozoa. Limnol Oceanogr 39:411-419

Fogel ML, Cifuentes LA (1993) Isotope fractionation during primary production. In: Engel $\mathrm{MH}$, Macko SA (eds) Organic geochemistry. Plenum, New York, p 168-204

Fry B (1988) Food web structure on Georges Bank from stable C. $N$, and $\mathrm{S}$ isotopic compositions. Limnol Oceanogr 33: $1182-1190$ 
Goldman JC, Caron DA, Andersen OK, Dennett MR (1985) Nutrient cycling in a microflagellate food chain. I. Nitrogen dynamics. Mar Ecol Prog Ser 24:231-242

Goldman JC. Caron DA, Dennett MR (1987) Regulation of gross growth efficiency and ammonium regeneration in bacteria by substrate C:N ratio. Limnol Oceanogr 32 : $1239-1252$

Hoch MP, Fogel ML, Kirchman DL (1992) Isotope fractionation associated with ammonium uptake by a marine bacterium. Lamnol Occanogr 37:1434-1446

Hoch MP, Fogel MF, Kirchman DL (1994) Isotope fractionation durng ammonium uptake by marine microbial assemblages. Geomicrobiol J 12:113-127

Jumars PA, Penry DL, Baross JA, Perry MJ, Frost BW (1989) Closing the microbial loop: dissolved carbon pathway to heterotrophic bacteria from incomplete ingestion, digestion and absorption in animals. Deep Sea Res 36 483-495

Libes SM. Deuser WG (1988) The isotope geochemistry of particulate nitrogen in the Peru upwelling area and the Gulf of Maine. Deep Sea Res 35:517-533

Lòpez-Veneroni D, Cifuentes LA (1994) Transport of dissolved organic nitrogen in Mississippi River plume and Louisiana continental shelf near surface waters. Estuaries 17:796-808

Macko SA, Estep MLF, Engel MH, Hare PE (1986) Kinetuc fractionation of stable nitrogen isotopes during amino acld transamination. Geochim Cosmochim Acta 50:2143-2146

Macko SA, Fogel (Estep) ML, Hare PE, Hoering TC (1987) Isotope fractionation of nitrogen and carbon in the synthesis of amino acids by microorganisms. Chem Geol (Isotope Geochemistry Symposium) 65:79-92

Mopper K, Lindroth P (1982) Diel and depth variations in dissolved free amino acids and ammonium in the Baltic Sea determined by shipboard HPLC analysis. Limnol Oceanogr 27:336-347

Nagata T, Kirchman DL (1990) Filtration-induced release of dissolved free amino acids: application to cultures of marine protozoa. Mar Ecol Prog Ser 68:1-5

Nagata T, Kirchman DL (1991) Release of dissolved free and combined amino acids by bacteriovorous marine flagellates. Limnol Oceanogr 36:433-443

Nagata T, Kirchman DL (1992) Release of dissolved organic matter by heterotrophic protozoa: implications for microbial food webs. Arch Hydrobiol Beih 35:99-109

Nakatsuka T, Handa N, Wada E, Wong CS (1992) The dynamic changes of stable isotopic ratios of carbon and nitrogen in suspended and sedimented particulate

This article was submitted to the editor organıc matter during a phytoplankton bloom. J mar Res $50: 267-296$

O Leary MH (1978) Heavy-atom isotope effects in enzymecatalyzed reactions. In: Gandour RD, Schowen RL (eds) Transition states of biochemical processes. Plenum, New York, p 285-316

Parsons TR, Maita Y, Lalli CM (1985) A manual of chemical and biological methods for seawater analysis. Pergamon, Oxford

Pomeroy AJ (1984) Direct count of bacteria perserved with Lugol iodine solution. Appl environ Microbiol 47: 1191-1192

Porter KG, Feig YS (1980) The use of DAPI for identifying and counting aquatic microflora. Limnol Oceanogr 22:26-37

Rassoulzadegan F, Sheldon RW (1986) Predator-prey interactions of nanoplankton and bacteria in an oligotrophic marine environment. Limnol Oceanogr 31:1010-1021

Rau GH, Teyssie JL, Rassoulzadegan F, Fowler SW (1990) ${ }^{13} \mathrm{C} /{ }^{12} \mathrm{C}$ and ${ }^{15} \mathrm{~N} /{ }^{14} \mathrm{~N}$ variations among size-fractionated marine particles: implications for their origin and trophic relationships. Mar Ecol Prog Ser 59:33-38

Saino T, Hattori A (1980) ${ }^{15} \mathrm{~N}$ natural abundance in oceanic suspended particulate matter. Nature 283:752-754

Sherr BF, Sherr EB, Berman T (1982) Decomposition of organic detritus: a selective role for microflagellate protozoa. Limnol Oceanogr 27:765-769

Sherr BF, Sherr EB, Pedrós-Alió P (1989) Simultaneous measurement of bacterioplankton production and protozoan bacterivory in estuarine water. Mar Ecol Prog Ser 54: $209-219$

Suttle CA, Fuhrman JA, Capone DG (1990) Rapid ammonium cycling and concentration-dependent partitioning of ammonium and phosphate: implications for carbon transfer in planktonic communities. Limnol Oceanogr 35: $424-433$

Velinsky DJ, Cifuentes LA, Pennock JR, Sharp JH, Fogel MF (1989) Determination of the isotope composition of $\mathrm{NH}_{4}{ }^{+}-$ nitrogen at the natural abundance level from estuarine waters. Mar Chem 26:351-361

Wada E (1980) Nitrogen isotope fractionation and its significance in biogeochemical processes occurring in marine environments. In: Goldberg ED, Horibe Y, Saruhashi K (eds) Isotope marine chemistry. Vehido Rokakuho, Tokyo, p 375-398

Wada E. Terazaki $\mathrm{M}$, Kabaya $\mathrm{Y}$, Nemoto $\mathrm{T}(1987){ }^{15} \mathrm{~N}$ and ${ }^{13} \mathrm{C}$ abundances in the Antarctic Ocean with emphasis on the blogeochemical structure of the food web. Deep Sea Res 34:829-841

Manuscript first received: March 17, 1994

Revised version accepted: August 10, 1995 